\title{
How Much Is the Abandonment of Forest Management in Private Forests Worth? A Case of Poland
}

\author{
Piotr Tadeusz Gołos ${ }^{1}$, Joanna Ukalska ${ }^{2}$, Emilia Wysocka-Fijorek ${ }^{3, * \mathbb{C}}$ and Wojciech Gil ${ }^{4}$ \\ 1 Forest Research Institute, Sẹkocin Stary, 3 Braci Leśnej Street, 05-090 Raszyn, Poland; p.golos@ibles.waw.pl \\ 2 Laboratory of Dendrometry and Forest Productivity, Department of Forest Management Planning, \\ Dendrometry and Forest Economics, Institute of Forest Sciences, Warsaw University of Life Sciences, \\ Nowoursynowska 159, 02-776 Warsaw, Poland; joanna_ukalska@sggw.edu.pl \\ 3 Department of Forest Resources Management, Forest Research Institute, Sękocin Stary, 3 Braci Leśnej Street, \\ 05-090 Raszyn, Poland \\ 4 Department of Silviculture and Genetics of Forest Trees, Forest Research Institute, Sękocin Stary, \\ 3 Braci Leśnej Street, 05-090 Raszyn, Poland; W.Gil@ibles.waw.pl \\ * Correspondence: e.wysocka-fijorek@ibles.waw.pl; Tel.: +48-506-344-627
}

\section{check for} updates

Citation: Gołos, P.T.; Ukalska, J.; Wysocka-Fijorek, E.; Gil, W. How Much Is the Abandonment of Forest Management in Private Forests Worth? A Case of Poland. Forests 2021, 12, 1138. https://doi.org/ 10.3390/f12091138

\section{Academic Editors:}

Rosa Gallardo-Cobos,

Pedro Sánchez-Zamora and

Pilar Fernandez-Rebollo

Received: 2 July 2021

Accepted: 20 August 2021

Published: 24 August 2021

Publisher's Note: MDPI stays neutral with regard to jurisdictional claims in published maps and institutional affiliations.

Copyright: (c) 2021 by the authors. Licensee MDPI, Basel, Switzerland. This article is an open access article distributed under the terms and conditions of the Creative Commons Attribution (CC BY) license (https:// creativecommons.org/licenses/by/ $4.0 /)$.

\begin{abstract}
The provision of forest ecosystem services (such as biodiversity, water and soil protection, and recreation) is often associated with a reduction in timber harvesting. In the case of private forests, such a situation requires institutional solutions that allow the economic balance of forest management to be maintained. The aim of the study was to find out the average value of monetary compensation private forest owners would expect in case of timber harvesting restrictions. The study was conducted with a random sample of 1003 forest landowners. The average value of expected compensation ranged from PLN 2300/year/ha (which corresponds to the price of about $12 \mathrm{~m}^{3}$ of wood in Poland) under the condition of no restrictions on timber harvesting but the need to apply indicated of forest management methods, to PLN 4900/year/ha in the model assuming a total ban on harvesting. In general, higher compensation was expected by farmers who stated that they sold timber and those whose agricultural area was larger than the average in Poland. When harvesting restrictions are low, the expected compensation is influenced by the age and gender of the respondent, or the number of people in the household.
\end{abstract}

Keywords: ecosystem services; stakeholders; forest policy; timber harvesting; forest management

\section{Introduction}

With the ongoing evolution of multifunctional and sustainable forest management, it is seen as one way to mitigate environmental disturbances, the dynamics of which have been visibly increasing since the beginning of the 21st century [1,2]. It is believed that forests can play a greater role in mitigating climate change and maintaining biodiversity [3-6]. However, many studies indicate that the potential of ecosystem services [7] may have an impact in the form of reduced timber harvesting [8-13]. Achieving a balance between the expected social and natural value of the forest and the objectives of forest management requires the implementation of well-chosen and diverse forest policy tools, i.e., methods for formulating collective action to ensure the public good [14]. In Europe, owners of private forests, which in all 28 countries of the EU occupy about $60 \%$ of the forest area [15], must be involved in the efficient implementation of policies to reach the established goals concerning various aspects of ecosystem services [16,17]. Forest policy solutions, directed at owners, should take into account the fragmentation of the forests, the ownership structure, objectives, and value system of forest owners, and the political, cultural and historical context [18,19].

One of the many applicable forest policy instruments is direct payments to forest owners $[20,21]$. This solution is of particular importance for this form of forest ownership, as it compensates for the effects of measures aimed at improving the quality and/or quantity of those forest ecosystem services (FESs) that infringe on ownership rights. The 
correct calculation of such payments can determine the level of commitment of private forest owners to sustainable forest land use [22] and the effectiveness of programmes that intensify the provision of these ecosystem services. Owners should have the right to choose from a variety of programmes [23], which would guarantee that the economic balance of forest management will be maintained. Along with voluntary programmes based on the intrinsic motivation of owners (which do not require the involvement of public funds), programmes based on extrinsic motivation should be available, according to the self-determination theory [24]. This theory foresees, among others, a system of financial compensation [22] that could support the generation of public value [23]. Such a solution seems particularly desirable under the conditions of a lack of effectiveness of current political solutions and legal regulations, when there is a growing concern that public benefits from private forest ownership will be insufficiently provided within current forest management systems [25].

The expectation of financial compensation for timber harvesting restrictions by owners is a natural reaction, especially for those who apply their experience with CAP payments for agricultural management in the area of forest management. In the case of owners who are not professionally related to rural areas, their expectations in this regard are impacted by non-economic factors [26,27], which makes this group willing to support FES in decisions related to the management of their own forest land [28]. The high interest of farmers in Poland in CAP funding to support afforestation of land excluded from agricultural production [29] indicates that financial forest policy instruments may be of great interest to forest owners [30,31].

The main objective of the research was to find out the average value of expected monetary compensation (willingness to accept (WTA)) by a forest owner (farmer) that could balance the value of losses in forest management caused by timber harvesting restrictions. In the analysis of the results, an attempt was made to establish a relationship between the declared WTA value and selected explanatory variables established in the research using a questionnaire survey. The question was, therefore, what compensation would private forest owners expect for limiting the possibility of logging. The problem of limiting logging and the related compensation for private forest owners is an important issue in the draft EU forestry strategy. This is also a particularly important issue in view of the need to implement the EU biodiversity strategy for 2030 or LULUCF actions.

\section{Materials and Methods}

\subsection{Research Object}

An analysis of the results of the survey requires a presentation of the basic information about private forests in Poland. They cover an area of 1788 thousand ha $(19.2 \%$ of the forest area), including 1683 thousand ha of forest belonging to persons, among whom the largest group are farmers; there are -544 thousand individual farms, where forests cover 863 thousand ha [32]. The average age of forest stands is 50 years, the average volume is $249 \mathrm{~m}^{3} /$ ha, the average current volume increment is about $9 \mathrm{~m}^{3} / \mathrm{ha}$, and the average volume of standing and lying dead trees is about $6 \mathrm{~m}^{3} / \mathrm{ha}$; the average for forests of all forms of ownership is $8 \mathrm{~m}^{3} /$ ha [33]. Farmers usually manage 2-3 forest plots, the smallest of which have an average area of $0.21-0.35$ ha and the largest about $1.92-2.83$ ha $[34,35]$. Timber harvesting in private forests in 2018 amounted to about 1830 thousand $\mathrm{m}^{3}$ of timber [36], which was $4 \%$ of the total harvest in Poland. The results of the large-scale forest inventory (WISL) show that the timber harvest in private forests can be about $3.5 \mathrm{~m}^{3} /$ ha/year [33], i.e., about 6 million $\mathrm{m}^{3}$. Only a small part of the harvested wood is sold; most of the wood is used by the owners as fuel or for agricultural needs [35].

\subsection{Survey Research}

The presented research is the first attempt in Poland to estimate the value of hypothetical financial compensation for private forest owners in the case of timber harvesting 
restrictions. For this purpose, the contingent valuation method (CVM) and an open question on willingness to accept (WTA) were used [37-39].

The research was conducted on a representative large, random nationwide sample of forest landowners who are farmers (1003 survey questionnaires). The survey was conducted in April 2019 by the Kantar agency on behalf of the Polish Forest Research Institute. It used the computer assisted personal interview (CAPI) method with a standardised interview questionnaire that included 16 factual questions and a respondent metric. The sample had a quota and random character and was selected from the address database of the Central Statistical Office (CSO). The stratification took into account the presence of private forests in a given province. The stratification was based on CSO data collected in the 2010 General Agricultural Census (GAC).

The surveyed population was stratified according to the criterion of territorial location (under division into 16 voivodeships; NUTS 2), taking into account the forest presence, i.e., the share of respondents from a given voivodeship in the sample was proportional to the share of farms that included private forests in a given voivodeship for all farms of this type in Poland. Districts were selected within the framework of the stratified division, which at a later stage constituted the units for drawing addresses. Such a draw was made with probabilities proportional to the number of farmers/owners of private forests, with the number of drawn districts being determined on the assumption that the same number of interviews (equal to the size of the performance bundle) were performed in each district (5 respondents). The drawing of districts was performed according to the scheme with return.

At the performance stage, the interviewer started searching for a respondent at the starting point drawn in the designated district, and then searched for respondents (private forest owners) in the area of the given district near this respondent. If a person meeting the specified criteria lived on a drawn farm and agreed to participate in the research, an interview was conducted with this person. If the person was a private forest owner and did not live on the farm or the interviewer did not obtain permission to conduct an interview at that address, the search for a respondent continued with the next farm. Of the four forest management alternatives described, respondents were asked to indicate the WTA amount (PLN/year/ha) for each one that reduced the amount of timber extracted to date. The question was asked in an open-ended format to avoid suggesting "too low" or "too high" values in the payment cards, which could affect the reliability of the research.

The question on WTA consisted of two parts. In the first part, the respondent was introduced to the valuation issue (the valuation context was provided) with the following reminder: "The main benefit to you as a forest owner is the ability to use the timber harvested in the forest for your household and farming". The second part asked the respondent to indicate the financial amount expected as financial compensation if he/she were forced to restrict timber harvesting. The respondents were shown the units of hypothetical WTA value (period and area) and asked to enter the amount of PLN/year/ha for each of the four levels of restrictions, bearing in mind the total benefits from the forest they would have to give up. The main criterion adopted in formulating the descriptions of the four proposed restrictions (each was treated as a separate model in the subsequent analysis) was to create the conditions for easy assessment by respondents of the balance of costs and benefits of the hypothetical forest management restrictions, which were as follows:

(1) Total restriction on timber harvesting in the forest (WTA1);

(2) Restriction on timber harvesting corresponding to $50 \%$ of the amount the owners currently harvest (WTA2);

(3) No restriction on timber harvesting, but the need to apply methods of silviculture, protection and forest use indicated in a forest management plan (WTA3);

(4) Restriction on timber harvesting consisting of leaving the oldest single trees (5\% of trees) in the forest (WTA4). 


\subsection{Statistical Analysis}

In each of the four models (WTA variable), the relationships and correlations between the declared WTA value and selected explanatory variables were examined, considering the following:

(1) Social and economic variables, including gender (male, female); age (years); education (primary, basic vocational, secondary, higher); professional activity of farmers (Farmer, F), (farmers who stated that they ran a farm, others) and number of persons in the household of the interviewed person ( $\mathrm{Nph}$ );

(2) Variables differentiating the researched farms in terms of the average surface area of used land, including: agricultural land (Agri_above_average, Aaa), (average surface area higher than the national average, others), and forest land (Forest_above_averageFaa) (average area higher than the national average, others);

(3) Variables defined in the research survey and concerning knowledge of Natura 2000 (N2000), (yes, other answers); definition of Natura 2000 sites (N2000def) (1, correct definition; 0, other); evaluation of the possibility of joint sales of timber (Jts) as a benefit of the respondent's membership in a forestry association ( 1 , score 4 or lower; 0 , others); ways that respondent used harvested timber (1, respondent sells timber (timber sales, TS); 0, others); respondent's assessment of the function of the forest as a source of raw timber ( 1 , respondent assigned $\geq 20$ points (source of raw timber, $T ; 0$, others).

The explanatory variables included two quantitative variables (A and Nph), one qualitative variable (E), and eight dichotomous variables. The values of the response variable WTA assigned by the respondents in each of the four models (WTA 1-4) were verified by cutting off $5 \%$ of the maximum values and removing all records with the same WTA value located at the cut-off (95th percentile). The verification reduced the number of interviews included in the analysis in models 1-4 to 956, 953, 950 and 953 survey questionnaires, respectively.

Multiple regression analysis was used to analyse the relationship between the WTA response variable and explanatory variables. The selection of the model was based on the principle of selecting the smallest possible set of explanatory variables (parsimonious model). As a selection method, stepwise selection with a stopping rule based on 5-fold cross validation was applied. A stopping rule was used, in which the addition and removal of model effects (variables) were treated competitively. The selection criterion (the AIC) was evaluated for all models by deleting an effect from the current model or adding an effect to this model. This approach differs from the usual implementation of stepwise selection, in which all effects whose removal improves the selection criterion are discarded before any effect is considered for addition to the model [40]. If there were non-significant variables in the model selected in the manner described above, they were not included in the final model. Calculations were performed using the GLMSELEC, GLM, and MIXED procedures of the SAS SAS/STAT ${ }^{\circledR}$ v. 14.3 software [41].

\subsection{Currency Conversions}

The average value of the estimated WTA parameter in Table 4 is given in PLN and converted into EUR, according to the exchange rate of the National Bank of Poland on 30 April 2019. (EUR $1=$ PLN 4.2911) [42]. The results in the descriptive part are presented in PLN.

\section{Results}

The average surface area of agricultural land on the researched farms (Table 1) was lower than the average for Poland, which was 10.9 ha in 2019 [32]. In the case of forest and other land, the average on the researched farms was higher than the average for Poland, which was, respectively, 1.5 ha [36] and 0.72 ha [32] in 2019. 
Table 1. Characteristics of researched farms established by survey conducted in April 2019 based on random representative nationwide sample of forest owners (farmers).

\begin{tabular}{|c|c|c|c|c|c|c|c|}
\hline Research Sample Variables & Average & Median & SD & $\mathrm{CV}$ & Min. & Max. & N (95th Percentile) \\
\hline Agricultural land area (ha) & 10.36 & 6.00 & 13.86 & $134 \%$ & 0.0 & 100 & 953 \\
\hline Forest land area (ha) & 3.43 & 1.50 & 6.33 & $185 \%$ & 0.1 & 60 & 953 \\
\hline Other land area (ha) & 1.30 & 0.00 & 3.44 & $264 \%$ & 0.0 & 40 & 953 \\
\hline Household income (net PLN/household/month) & 3183.60 & 2590.60 & 2616.90 & $82 \%$ & 0 & $>15,000$ & 516 \\
\hline
\end{tabular}

The average net monthly income of the researched farms with more than three persons was almost PLN 3200 . The survey sample included predominantly males $(61.07 \%)$ and the average age of respondents was over 51 (Table 2). More than half of the respondents $(57 \%)$ stated that they ran a farm. Approximately $26 \%$ of the researched farms had a larger surface area of forest land than agricultural land on average 6.44 ha of forest. Knowledge of Natura 2000 was reported by $62 \%$ and the correct definition of Natura 2000 sites by $40 \%$ of the respondents. The average surface area of forest land on farms where it was larger than agricultural land, was almost twice the average for the whole sample (6.44 ha) and very close to the average area of forest land of farms on which the average forest area was larger than the average for Poland (6.22 ha).

Table 2. Descriptive statistics for explanatory variables included in WTA analysis of survey reScheme 2019. on random representative nationwide sample of forest owners (farmers). SD, standard deviation; $\mathrm{CV}$, coefficient of variation.

\begin{tabular}{|c|c|c|c|c|c|c|c|c|}
\hline Explanatory Variables & $\%$ & Average & Median & SD & $\mathrm{CV}$ & Min. & Max. & $\mathbf{N}$ \\
\hline Gender (G) & 61.07 & - & - & - & - & - & - & 582 \\
\hline Male/Female & 38.93 & - & - & - & - & - & - & 371 \\
\hline Age (A) (years) & & 51.05 & 51 & 11.508 & $23 \%$ & 21 & 86 & 953 \\
\hline \multicolumn{9}{|l|}{ Education (E) } \\
\hline Basic & 7.14 & - & - & - & - & - & - & 68 \\
\hline Vocational & 38.4 & - & - & - & - & - & - & 366 \\
\hline Secondary & 41.03 & - & - & - & - & - & - & 391 \\
\hline Higher & 13.43 & - & - & - & - & - & - & 128 \\
\hline $\begin{array}{l}\text { Farmer }(\mathbf{F}) \text { : Respondents who indicated that they } \\
\text { ran a farm }(\%)\end{array}$ & 57 & - & - & 0.495 & $87 \%$ & 0 & 1 & 546 \\
\hline $\begin{array}{l}\text { No_persons_household (Nph): Number of persons } \\
\text { in respondent's household (respondents) }\end{array}$ & - & 3.27 & 3 & 1.447 & $44 \%$ & 1 & 12 & 953 \\
\hline $\begin{array}{l}\text { Forest_greater }(\mathbf{F g}) \text { : Farms with forest area greater } \\
\text { than or equal to agricultural area (ha) }\end{array}$ & - & 6.44 & 2 & 10.04 & $156 \%$ & 0.1 & 60 & 267 \\
\hline $\begin{array}{l}\text { Natura } 2000 \text { (N2000): Respondents who indicated } \\
\text { knowledge of Natura } 2000(\%)\end{array}$ & 62 & - & - & 0.487 & $79 \%$ & 0 & 1 & 588 \\
\hline $\begin{array}{l}\text { Definition of Natura } 2000 \text { sites (N2000def): } \\
\text { Respondents who indicated correct definition of } \\
\text { Natura } 2000 \text { sites (\%) }\end{array}$ & 40 & - & - & 0.489 & $124 \%$ & 0 & 1 & 378 \\
\hline $\begin{array}{l}\text { Joint sale of timber raw material (Jts): Scores of } \leq 4 \\
\text { assigned by respondents for benefits of joint sales of } \\
\text { timber raw material (pts.). (Respondents evaluated } \\
\text { benefits on a scale of } 1 \text { to } 8 \text {, where } 1=\text { most } \\
\text { important benefit, } 8=\text { least important benefit; } \\
\text { average for whole sample was } 4.40 \text {.) }\end{array}$ & - & 2.77 & 3 & 1.10 & $40 \%$ & 1 & 4 & 495 \\
\hline $\begin{array}{l}\text { Timber sales (Ts): Proportion of respondents who } \\
\text { stated that they sold timber (\%). (Respondents were } \\
\text { asked to provide \% structure of timber harvested in } \\
\text { their forest for use as fuel, for farm use and sold.) }\end{array}$ & - & 33.85 & 30 & 25.13 & $74 \%$ & 1 & 100 & 420 \\
\hline $\begin{array}{l}\text { Timber }(\mathrm{T}) \text { : Scores of } \geq 20 \text { assigned by respondents } \\
\text { for importance of forest as source of timber (pts.). } \\
\text { (Respondents were asked to divide } 100 \text { points } \\
\text { among } 8 \text { most important functions, including forest } \\
\text { as a source of timber; average for whole sample was } \\
19.44 \text { points.) }\end{array}$ & - & 29.53 & 25 & 13.74 & $47 \%$ & 20 & 100 & 476 \\
\hline $\begin{array}{l}\text { Agri_above_average (Aaa): Farms where } \\
\text { agricultural land area was greater than the average } \\
\text { for Poland (ha) }{ }^{1}\end{array}$ & - & 22.34 & 16 & 17.44 & $78 \%$ & 9.8 & 100 & 398 \\
\hline $\begin{array}{l}\text { Forest_above_average (Faa): Farms on forest area } \\
\text { larger than the Polish average (ha) }{ }^{1}\end{array}$ & - & 6.22 & 3 & 8.10 & $130 \%$ & 1.6 & 60 & 496 \\
\hline
\end{tabular}

${ }^{1}$ Average surface area of agricultural land according to CSO data (2019) was 10.9 ha, while surface area of forest land was 1.5 ha. 
The average WTA value in the four models ranged from PLN 4900/year/ha in WTA1 (assuming a total ban on timber harvesting), to PLN 2300/year/ha in WTA3 (no restriction on timber harvesting, but the need to apply indicated methods of forest management) and PLN 2400/year/ha in WTA4 (restriction on timber harvesting to leaving the oldest single trees in the forest) (Table 3). In the case of WTA2 (timber harvesting restricted to 50\%), the average WTA value was over PLN 2700/year/ha (approximately $56 \%$ of the value in WTA1).

Table 3. Descriptive statistics of WTA variables in analysed models in survey research conducted in April 2019 on random representative nationwide sample of forest owners (farmers). SD, standard deviation; $\mathrm{CV}$, coefficient of variation.

\begin{tabular}{|c|c|c|c|c|c|c|c|}
\hline Variables & $\begin{array}{c}\text { Average } \\
\text { (PLN/year/ha/ } \\
\text { (EUR/year/ha)) }\end{array}$ & $\begin{array}{c}\text { Median } \\
\text { (PLN/year/ha/ } \\
\text { (EUR/year/ha)) }\end{array}$ & SD & $\mathrm{CV}$ & $\begin{array}{c}\text { Min. } \\
\text { (PLN/year/ha/ } \\
\text { (EUR/year/ha)) }\end{array}$ & $\begin{array}{c}\text { Max. } \\
\text { (PLN/year/ha/ } \\
\text { (EUR/year/ha)) }\end{array}$ & N (95th Percentile) \\
\hline $\begin{array}{l}\text { WTA1: Total restriction on timber } \\
\text { harvesting in forest }\end{array}$ & $4890.8(1139.75)$ & $3000(699.12)$ & 6048.1 & $124 \%$ & 0 & $30,000(6991.21)$ & 956 \\
\hline $\begin{array}{l}\text { WTA2: Restriction on timber } \\
\text { harvesting to } 50 \% \text { of what is } \\
\text { currently harvested }\end{array}$ & $\begin{array}{c}2738.4 \\
(638.16)\end{array}$ & $2000(466.08)$ & 2985.1 & $109 \%$ & 0 & $17,500(4078.20)$ & 953 \\
\hline $\begin{array}{l}\text { WTA3: No restrictions on timber } \\
\text { harvesting, but the need to apply } \\
\text { indicated methods of silviculture, } \\
\text { protection and forest use }\end{array}$ & $\begin{array}{c}2361.3 \\
(550.28)\end{array}$ & $1000(233.04)$ & 2638.2 & $112 \%$ & 0 & $12,000(2796.49)$ & 950 \\
\hline $\begin{array}{l}\text { WTA4: Restriction on timber } \\
\text { harvesting to leaving oldest } \\
\text { single trees in forest }\end{array}$ & $\begin{array}{c}2387.2 \\
(556.31)\end{array}$ & $1000(233.04)$ & 2682.9 & $112 \%$ & 0 & $13,000(3029.53)$ & 953 \\
\hline
\end{tabular}

The regression analysis revealed dichotomous and quantitative variables that differentiated the study sample in terms of mean WTA value in each of the analysed models (Tables 4-7).

Table 4. Results of multiple regression analysis of response variable WTA1 on explanatory variables (variable values: 1, yes; 0, no; parameter estimate: expected WTA1 value) in research conducted in April 2019 on a random representative nationwide sample of forest owners (farmers). SE, standard error.

\begin{tabular}{|c|c|c|c|c|c|c|c|c|}
\hline Variable $^{1}$ & $\mathbf{N}$ & Variable Value & Parameter Estimate & $\mathrm{SE}$ & \multicolumn{2}{|c|}{ Confidence Interval } & $\mathbf{t}$ & $p$ \\
\hline \multirow{2}{*}{ Timber sales (Ts) } & 420 & Yes & 5828 & 292 & 5254 & 6401 & \multirow{2}{*}{4.13} & \multirow{2}{*}{$<0.001$} \\
\hline & 536 & No & 4219 & 270 & 3689 & 4749 & & \\
\hline \multirow{2}{*}{ Farmer $(F)$} & 546 & Yes & 5526 & 259 & 5017 & 6035 & \multirow{2}{*}{2.35} & \multirow{2}{*}{0.019} \\
\hline & 410 & No & 4520 & 327 & 3879 & 5162 & & \\
\hline Age $(\mathrm{A})^{2}$ & - & - & $-46.6^{1}$ & 16.8 & -79.6 & -13.6 & -2.77 & 0.006 \\
\hline \multirow{2}{*}{ Agri_above_average (Aaa) } & 398 & Yes & 5500 & 335 & 4843 & 6157 & \multirow{2}{*}{2.22} & \multirow{2}{*}{0.027} \\
\hline & 558 & No & 4546 & 250 & 4055 & 5037 & & \\
\hline \multirow{2}{*}{ Timber $(\mathrm{T})$} & 476 & Yes & 5420 & 285 & 4861 & 5979 & \multirow{2}{*}{2.05} & \multirow[b]{2}{*}{0.041} \\
\hline & 480 & No & 4627 & 276 & 4086 & 5168 & & \\
\hline
\end{tabular}

${ }^{1}$ Only significant explanatory variables included in final model are reported. ${ }^{2}$ Parameter estimate for quantitative variable Age means change in WTA when respondent's age increases by one year.

Table 5. Results of multiple regression analysis of response variable WTA2 on explanatory variables (variable values: 1 , yes; 0, no; parameter estimate: expected value of WTA2) in research conducted in April 2019 on a random representative nationwide sample of forest owners (farmers). SE, standard error.

\begin{tabular}{|c|c|c|c|c|c|c|c|c|}
\hline Variable $^{1}$ & $\mathbf{N}$ & Variable Value & Parameter Estimate & $\mathrm{SE}$ & \multicolumn{2}{|c|}{ Confidence Interval } & $t$ & $p$ \\
\hline \multirow{2}{*}{ Timber sales (Ts) } & 420 & Yes & 3403 & 152 & 3105 & 3700 & \multirow[b]{2}{*}{4.51} & \multirow{2}{*}{$<0.001$} \\
\hline & 533 & No & 2530 & 149 & 2238 & 2821 & & \\
\hline \multirow{2}{*}{ Farmer $(\mathrm{F})$} & 546 & Yes & 3335 & 154 & 3033 & 3636 & \multirow[b]{2}{*}{3.39} & \multirow[b]{2}{*}{$<0.001$} \\
\hline & 407 & No & 2597 & 162 & 2279 & 2916 & & \\
\hline No_persons_household $(\mathrm{Nph})^{2}$ & - & - & $220^{1}$ & 66 & 91 & 350 & 3.35 & $<0.001$ \\
\hline \multirow{2}{*}{ Forest_above_average (Faa) } & 496 & Yes & 3162 & 140 & 2888 & 3436 & \multirow{2}{*}{1.96} & \multirow{2}{*}{0.050} \\
\hline & 457 & No & 2770 & 168 & 2440 & 3100 & & \\
\hline \multirow{2}{*}{ Gender $(G)$} & 374 & $\mathrm{~F}$ & 3224 & 164 & 2901 & 3546 & \multirow[b]{2}{*}{2.65} & \multirow[b]{2}{*}{0.008} \\
\hline & 579 & $\mathrm{M}$ & 2709 & 135 & 2443 & 2974 & & \\
\hline
\end{tabular}


Table 5. Cont.

\begin{tabular}{|c|c|c|c|c|c|c|c|c|}
\hline Variable $^{1}$ & $\mathbf{N}$ & Variable Value & Parameter Estimate & SE & \multicolumn{2}{|c|}{ Confidence Interval } & $t$ & $p$ \\
\hline \multirow{2}{*}{ Agri_above_average (Aaa) } & 398 & Yes & 3204 & 190 & 2832 & 3577 & \multirow{2}{*}{2.11} & \multirow{2}{*}{0.035} \\
\hline & 555 & No & 2728 & 126 & 2481 & 2975 & & \\
\hline \multirow{2}{*}{ Forest_greater (Fg) } & 267 & Yes & 3216 & 203 & 2818 & 3615 & \multirow{2}{*}{2.05} & \multirow{2}{*}{0.041} \\
\hline & 686 & No & 2716 & 122 & 2476 & 2956 & & \\
\hline
\end{tabular}

${ }^{1}$ Only significant explanatory variables included in final model are reported. ${ }^{2}$ Parameter estimate for quantitative variable Nph represents change in WTA2 with an increase in the value of the variable by one person per household.

Table 6. Results of multiple regression analysis of response variable WTA3 on explanatory variables (variable values: 1 , yes; 0, no; parameter estimate: expected value of WTA3) in research conducted in April 2019 on a random representative nationwide sample of forest owners (farmers). SE, standard error.

\begin{tabular}{|c|c|c|c|c|c|c|c|c|}
\hline Variable $^{1}$ & $\mathbf{N}$ & Variable Value & Parameter Estimate & SE & \multicolumn{2}{|c|}{ Confidence Interval } & $t$ & $p$ \\
\hline \multirow{2}{*}{ Forest_above_average (Faa) } & 496 & Yes & 2823 & 124 & 2580 & 3066 & \multirow[b]{2}{*}{3.42} & \multirow[b]{2}{*}{$<0.001$} \\
\hline & 454 & No & 2222 & 134 & 1960 & 2484 & & \\
\hline No_persons_household (Nph) ${ }^{2}$ & - & - & $221^{1}$ & 58 & 107 & 336 & 3.8 & $<0.001$ \\
\hline \multirow{2}{*}{ Timber Sales (Ts) } & 420 & Yes & 2837 & 131 & 2580 & 3093 & \multirow{2}{*}{3.66} & \multirow{2}{*}{$<0.001$} \\
\hline & 530 & No & 2209 & 124 & 1965 & 2453 & & \\
\hline \multirow{2}{*}{ Gender (S) } & 372 & $\mathrm{~F}$ & 2714 & 137 & 2444 & 2984 & \multirow{2}{*}{2.23} & \multirow[b]{2}{*}{0.026} \\
\hline & 578 & M & 2331 & 117 & 2102 & 2561 & & \\
\hline \multirow{2}{*}{ Forest_greater (Fg) } & 267 & Yes & 2758 & 167 & 2430 & 3086 & \multirow{2}{*}{2.35} & \multirow{2}{*}{0.019} \\
\hline & 683 & No & 2287 & 108 & 2075 & 2499 & & \\
\hline \multirow{2}{*}{ Farmer (F) } & 546 & Yes & 2763 & 136 & 2497 & 3029 & \multirow{2}{*}{2.48} & \multirow{2}{*}{0.013} \\
\hline & 404 & No & 2282 & 130 & 2028 & 2537 & & \\
\hline
\end{tabular}

${ }^{1}$ Only significant explanatory variables included in final model are reported. ${ }^{2}$ Parameter estimate for quantitative variable Nph represents change in WTA3 with an increase in the value of the variable by 1.

Table 7. Results of multiple regression analysis of response variable WTA4 on explanatory variables (variable values: 1 , yes; 0, no; parameter estimate: expected value of WTA4) in research conducted in April 2019 on a random representative nationwide sample of forest owners (farmers). SE, standard error.

\begin{tabular}{|c|c|c|c|c|c|c|c|c|}
\hline Variable $^{1}$ & $\mathbf{N}$ & Variable Value & Parameter Estimate & SE & \multicolumn{2}{|c|}{ Confidence Interval } & $\mathbf{t}$ & $p$ \\
\hline No_persons_household $(\mathrm{Nph})^{2}$ & - & - & $237^{1}$ & 61 & 117 & 358 & 3.86 & $<0.001$ \\
\hline \multirow{2}{*}{ Forest_above_average (Faa) } & 496 & Yes & 2752 & 124 & 2509 & 2995 & \multirow[b]{2}{*}{2.33} & \multirow[b]{2}{*}{0.02} \\
\hline & 457 & No & 2339 & 135 & 2074 & 2604 & & \\
\hline \multirow{2}{*}{ Timber Sales (Ts) } & 420 & Yes & 2807 & 132 & 2549 & 3066 & \multirow{2}{*}{3.01} & \multirow{2}{*}{0.003} \\
\hline & 533 & No & 2284 & 125 & 2038 & 2529 & & \\
\hline Age (S) & - & - & $-18^{1}$ & 8 & -33 & -3 & -2.29 & 0.022 \\
\hline \multirow{2}{*}{ Forest_greater (Fg) } & 267 & Yes & 2901 & 168 & 2571 & 3232 & \multirow[b]{2}{*}{3.38} & \multirow[b]{2}{*}{$<0.001$} \\
\hline & 686 & No & 2190 & 108 & 1978 & 2401 & & \\
\hline \multirow{2}{*}{ Farmer $(F)$} & 546 & Yes & 2825 & 136 & 2559 & 3092 & \multirow{2}{*}{2.98} & \multirow{2}{*}{0.003} \\
\hline & 407 & No & 2266 & 131 & 2010 & 2522 & & \\
\hline
\end{tabular}

${ }^{1}$ Only significant explanatory variables included in final model are reported. ${ }^{2}$ Parameter estimate for quantitative variable. Age represents change in WTA4 with an increase in the value of the variable by 1.

In the WTA1 model (assuming the complete abandonment of logging), the regression analysis revealed significant differences in WTA values for the four dichotomous variables (Table 4). Higher compensation was expected by farmers who stated that they sold timber (Ts) and ran a farm (F), farmers whose agricultural land surface area was higher than the average for Poland (Aaa), and those who highly valued the importance of forest management as suppliers of timber raw material (T). However, the expected WTA value was found to decrease with an increase in the farmer's age (A).

In the WTA2 model (assuming a 50\% reduction in timber harvesting in relation to the volume of timber harvested to date), significant differences in values were found for six dichotomous variables (Table 5). Higher compensation was expected by owners who sold timber (Ts), who declared that they ran a farm (F), and who managed forest and agricultural land with a surface area larger than the average in Poland (Faa and Aaa, respectively). Owners whose forest area was larger than their agricultural land (Fg) also expected higher compensation. Furthermore, there was a difference between women and men $(\mathrm{G})$ : women 
expected more compensation. The average WTA value also increased with an increase in the number of persons in the household (Nph).

In the WTA3 model (assuming no restriction on timber harvesting but the need to apply the indicated methods of silviculture, protection, and forest use), significant differences were found for five dichotomous variables (Table 7). A higher WTA value was expected by owners with forest land surface area above the average for Poland (Faa), owners of farms with larger forest surface area than agricultural land area (Fg), and respondents who stated that they ran a farm (F). The WTA value was also impacted by timber sales (Ts) and gender, and increased with higher numbers of persons in the household.

In the WTA4 model (assuming leaving the oldest trees), the value of compensation increased as the number of persons in the respondent's household increased and decreased with the increase in the respondent's age (Table 7). Significant differences were found in the case of dichotomous variables related to the average surface area of forest land (Faa), timber sales activity (Ts), larger surface area of forest than agricultural land, and respondents who stated that they ran a farm.

The comparison of differences in WTA values for dichotomous variables and two quantitative variables (Nph and A) shows that the greatest difference occurred in the WTA1 model between owners selling timber and owners using timber as fuel and for household (agricultural) needs (WTA1-Ts) (Table 8). In this model, the highest WTA value for the research sample, PLN 5828/ha/year, was also recorded for the 420 owners who stated that they sold timber harvested in their forest. The lowest compensation was expected by owners of forests smaller than the surface area of agricultural land in the WTA4 model, PLN 2190/ha/year.

Table 8. Differences in mean WTA values for explanatory variables based on survey research conducted in April 2019 on a random representative nationwide sample of forest owners (farmers).

\begin{tabular}{|c|c|c|c|c|}
\hline \multirow{2}{*}{$\begin{array}{l}\text { Explanatory Variables for Which Statistically } \\
\text { Significant Differences in WTA Values Were Found }\end{array}$} & \multicolumn{4}{|c|}{ Maximum Value and Difference of WTA in Analysed Models (PLN/year/ha) } \\
\hline & WTA1 & WTA2 & WTA3 & WTA4 \\
\hline Timber sales (Ts) & 5828 & 3403 & none & 2807 \\
\hline Difference in WTA value for Ts & 1609 & 873 & & 523 \\
\hline Farmer $(\mathrm{F})$ & 5526 & 3335 & $2 \overline{7} 63$ & 2825 \\
\hline Difference in WTA value for F & 1006 & 738 & 481 & 559 \\
\hline Forest_above_average (Faa) & none & 3162 & 2823 & 2752 \\
\hline Difference in WTA value for Faa & - & 392 & 601 & 413 \\
\hline Forest_greater $(\mathrm{Fg})$ & none & 3216 & 2758 & 2901 \\
\hline Difference in WTA value for Fg & & 500 & 471 & 711 \\
\hline Agri_above_average (Aaa) & 5500 & 3204 & none & none \\
\hline Difference in WTA value for Aaa & 954 & 476 & & - \\
\hline Gender $(\mathrm{G})$ & none & 3224 & $2 \overline{7} 14$ & none \\
\hline Difference in WTA value for G & - & 515 & 383 & - \\
\hline No_persons_household $(\mathrm{Nph})^{1}$ & - & 220 & 221 & $2 \overline{3} 7$ \\
\hline Age $(\mathrm{A})^{2}$ & $-\overline{46} .6$ & - & - & -18 \\
\hline
\end{tabular}

${ }^{1}$ WTA change for quantitative variable Nph upon its increase by $1 .{ }^{2}$ WTA change for quantitative variable Age upon its increase by 1.

\section{Discussion}

Private forests in Poland account for almost 20\% of the country's forest area. Knowing the expectations of the owners of these forests regarding compensation for limiting the possibility of timber harvesting can be very important for successful implementation of the EU's biodiversity strategy for 2030 and forestry strategy or activities under LULUCF. Forest owners and managers need financial incentives to provide ecosystem services by protecting and restoring the forests, and to increase the resilience of the forests by managing them in the most climate- and biodiversity-friendly way, which can be achieved by limiting timber harvesting, among other methods. Sarvašová et al. [43,44] noted that the countries with the highest proportion of forest areas in the Natura 2000 protected areas receive the lowest compensation and that policy implementation is obviously not geared to the needs of private forests (if one takes the proportion of private forests in the country as a basis). WTA values indicate different expectations depending on the level of timber 
harvesting restrictions. They are also differentiated by the variables established in the surveys (Tables $5-8$ ).

The direction of changes in the average and median WTA values indicates that they decrease, from the model that assumes a total restriction on timber harvesting (WTA1) to the model in which there is no restrictions on harvesting (WTA3) and the one in which the restriction consists of leaving the oldest trees in the forest (WTA4), which was similar to the value determined in the WTA3 model in terms of the level of expected compensation. Such a result can be considered to be consistent with expectations, since direct alternative costs and financial losses increase with management restrictions [23]. The absolute value of expected compensation (Table 4) is relatively high, as it corresponds to the values of 25 , $14,12.1$, and $12.3 \mathrm{~m}^{3}$ of timber (the average price of $1 \mathrm{~m}^{3}$ of timber in 2019 in Poland was PLN 194.24 [45]), while the average annual timber volume harvested in private forests is about $6 \mathrm{~m}^{3} /$ ha/year [33].

When looking for explanations that could clarify this difference, it should be kept in mind that owners also take into account other non-economic factors in forest management [46] that impact their willingness to make an effort to provide ecosystem services $[47,48]$, but which may also determine the WTA value. The average WTA value set in the most conservative model, WTA1 (total ban on logging) would allow restrictions in the other models to be imposed on surface areas almost twice as large $(1.87,2.07$, and 2.05 ha in models WTA2, 3, and 4, respectively). The possibility to modify the assumptions of the owner financial support schemes is also provided by the analysis of the impact of explanatory variables within each model.

In the presented research, the value of expected compensation was affected by gender (in models WTA2 and 3), age (WTA1 and 4) and the number of persons in the household (WTA2, 3, and 4). The introduction of programs to limit forestry production may be limited to economic, social, and intrinsic motives, with significant crowding out occurring only between economic and intrinsic motives, i.e., intrinsic motives are likely to reduce the effectiveness of economic incentives (this is not the case for social motives) [46]. In addition, forest owners who stated that they ran a farm (all models), owners with forest surface area greater the Polish average and greater than the agricultural land surface area (WTA2, 3 , and 4), and respondents with agricultural land surface area greater than the national average had higher expected WTA values. In France, as in Poland, studies show strong substitutability between biodiversity conservation and timber production; the estimation results of the cost elasticity of biodiversity conservation also suggest the possibility of more ecologically demanding contracts with lower average cost [49]. In Denmark, WTA varied significantly among owners depending on their current management. The average WTA for owners who did not allow extended access to the general public was EUR 14/ha/year if they allowed access up to $15 \mathrm{~m}$ from roads and trails and EUR 28/ha/year if they allowed access anywhere in their forest. In contrast, the mean WTA for forest owners who allowed extended access was zero [50].

Due to the small number of European research studies, it is difficult to compare the obtained values with other results. In a Danish study, forest owners expected compensation of EUR 0.48/ha/year (for the whole property) in the form of tax relief for each percentage point of forest surface area excluded from use, and in the case of allowing public access up to $15 \mathrm{~m}$ from roads and paths, owners expected EUR 16/ha/year; in the case of guaranteeing access to every part of the forest, they expected EUR 32/ha/year [50]. In a Norwegian study, the annual WTA value per hectare was estimated at NOK 1800 (about EUR 180) [25]. The average value of compensation claims by Finnish forest owners related to harvesting restrictions was EUR 328.9/ha/year [51]. In a US study, owners in Minnesota expected a minimum of USD 59.29/ha for joining a water quality and wildlife habitat improvement programme [52]; owners in Massachusetts expected a minimum of USD 793.05/ha for biomass production for bio-energy purposes [53], and owners in Massachusetts and Vermont expected compensation of up to USD 1729/ha/year to continuously provide a variety of ecosystem services in their forests [54]. In pine stands in the 
southern USA, the WTA value ranged from USD 190.22 to 595.23/ha/year and increased with the intensity of forest management restrictions [47]. Our research and that of others suggests that the willingness of forest owners to accept compensation depends on the scale of forest management restrictions, especially in the case of high harvested timber volume $[50,55]$. Under such conditions, the value of compensation claims in relation to lost benefits increases $[25,51]$.

\section{Conclusions}

The presented results allow us to quantify for the first time the amount of hypothetical monetary compensation accepted by forest owners in Poland for lost benefits in forest management in relation to restrictions on timber harvesting. The utility of this kind of research in Poland is evidenced by the fact that $77 \%$ of Polish society agrees with providing compensation for the provision of FES other than wood production, and indicates the budgets of local governments or the central budget as the source of financing [56]. The research shows that in the case of total restrictions, the expected value of compensation for timber harvesting is higher when the respondent's farm and share of forest in its area is larger. The fact that the raw material could be sold on the market was also importantfarmers who used the raw material for their own farm purposes had lower financial expectations if there was a ban on felling trees than those who sold timber. In the case of less stringent harvesting restrictions, the level of expected compensation was impacted by more "sensitive" factors, such as the respondent's age (older respondents had more reasonable expectations), gender (women had greater expectations), and the number of persons in the household. Knowing the WTA value is important information from the perspective of implementing forest policy. Determining its absolute value and knowing the factors that impact it can facilitate the calculation of the cost of different conservation objectives [25].

Author Contributions: P.T.G.: Conceptualisation, methodology, investigation, analysis, writingreview and editing; J.U.: methodology, software, formal analysis, data curation, original draft preparation, writing — review and editing, visualisation; E.W.-F.: investigation, data curation, analysis, writing—original draft, W.G.: writing—original draft, writing—review and editing. All authors have read and agreed to the published version of the manuscript.

Funding: This work was supported by the Ministry of Science and Higher Education (Poland) [Research Project No. 900419] and Priority Program No. 5.5 "Interdisciplinary Ecological Education" (Contract No. 28/2019/Wn50/EE-ee/D) entitled: "Private ForestsPossibilities, Problems, Solutions" financed by the National Fund for Environmental Protection and Water Management National Fund for Environmental Protection and Water Management.

Data Availability Statement: The data that support the findings of this study are available from the Forest Research Institute (Poland), but restrictions apply to the availability of these data, which were used under licence for the current study and are thus not publicly available. The data are, however, available from the authors upon reasonable request and with permission from the Forest Research Institute (Poland).

Conflicts of Interest: The authors report no declaration of interest.

\section{References}

1. Winkel, G.; Jump, A. Perspectives on forest conservation: Building evidence at the frontier between policy and conservation science. Biodivers. Conserv. 2014, 23, 3359-3372. [CrossRef]

2. Winter, S.; Borrass, L.; Geitzenauer, M.; Blondet, M.; Breibeck, R.; Weiss, G.; Winkel, G. The impact of Natura 2000 on forest management: A socio-ecological analysis in the continental region of the European Union. Biodivers. Conserv. 2014, 23, 3451-3482. [CrossRef]

3. Augustynczik, A.L.D.; Gutsch, M.; Basile, M.; Suckow, F.; Lasch, P.; Yousefpour, R.; Hanewinkel, M. Socially optimal forest management and biodiversity conservation in temperate forests under climate change. Ecol. Econ. 2020, 169, 106504. [CrossRef]

4. Blattert, C.; Lemm, R.; Thürig, E.; Stadelmann, G.; Brändli, U.B.; Temperli, C. Long-term impacts of increased timber harvests on ecosystem services and biodiversity: A scenario study based on national forest inventory data. Ecosyst. Serv. 2020, 45, 101150. [CrossRef] 
5. Borrass, L.; Kleinschmit, D.; Winkel, G. The "German model" of integrative multifunctional forest management-Analysing the emergence and political evolution of a forest management concept. For. Policy Econ. 2017, 77, 16-23. [CrossRef]

6. Biber, P.; Felton, A.; Nieuwenhuis, M.; Lindbladh, M.; Black, K.; Bahýl', J.; Bingöl, Ö.; Borges, J.G.; Botequim, B.; Brukas, V.; et al. Forest Biodiversity, Carbon Sequestration, and Wood Production: Modeling Synergies and Trade-Offs for Ten Forest Landscapes Across Europe. Front. Ecol. Evol. 2020, 8, 547696. [CrossRef]

7. Costanza, R.; de Groot, R.; Braat, L.; Kubiszewski, I.; Fioramonti, L.; Sutton, P.; Farber, S.; Grasso, M. Twenty years of ecosystem services: How far have we come and how far do we still need to go? Ecosyst. Serv. 2017, 28, 1-16. [CrossRef]

8. Paillet, Y.; Bergès, L.; HjÄltén, J.; Ódor, P.; Avon, C.; Bernhardt-Römermann, M.; Bijlsma, R.J.; De Bruyn, L.; Fuhr, M.; Grandin, U.; et al. Biodiversity differences between managed and unmanaged forests: Meta-analysis of species richness in Europe. Conserv. Biol. 2010, 24, 101-112. [CrossRef]

9. Gamfeldt, L.; Snäll, T.; Bagchi, R.; Jonsson, M.; Gustafsson, L.; Kjellander, P.; Ruiz-Jaen, M.C.; Fröberg, M.; Stendahl, J.; Philipson, C.D.; et al. Higher levels of multiple ecosystem services are found in forests with more tree species. Nat. Commun. 2013, 4, 1-8. [CrossRef]

10. Jucker, T.; Bouriaud, O.; Avacaritei, D.; Coomes, D.A. Stabilizing effects of diversity on aboveground wood production in forest ecosystems: Linking patterns and processes. Ecol. Lett. 2014, 17, 1560-1569. [CrossRef]

11. Bugalho, M.N.; Dias, F.S.; Briñas, B.; Cerdeira, J.O. Using the high conservation value forest concept and Pareto optimization to identify areas maximizing biodiversity and ecosystem services in cork oak landscapes. Agrofor. Syst. 2016, 90, 35-44. [CrossRef]

12. Felton, A.; Hedwall, P.O.; Lindbladh, M.; Nyberg, T.; Felton, A.M.; Holmström, E.; Wallin, I.; Löf, M.; Brunet, J. The biodiversity contribution of wood plantations: Contrasting the bird communities of Sweden's protected and production oak forests. For. Ecol. Manag. 2016, 365, 51-60. [CrossRef]

13. Felton, A.; Löfroth, T.; Angelstam, P.; Gustafsson, L.; Hjältén, J.; Felton, A.M.; Simonsson, P.; Dahlberg, A.; Lindbladh, M.; Svensson, J.; et al. Correction to: Keeping pace with forestry: Multi-scale conservation in a changing production forest matrix. Ambio 2020, 49, 1065-1066. [CrossRef] [PubMed]

14. The Tools of Government: A Guide to the New Governance: Salamon, Lester M.: 9780195136654: Amazon.com: Books. Available online: https: / www.amazon.com/Tools-Government-Guide-New-Governance/dp/0195136659 (accessed on 27 May 2021).

15. Agriculture, Forestry and Fishery Statistics-2018 Edition-Products Statistical Books-Eurostat. 2018. Available online: https: / / ec.europa.eu/eurostat/web/products-statistical-books/- /KS-FK-18-001 (accessed on 27 May 2021).

16. Primmer, E.; Varumo, L.; Krause, T.; Orsi, F.; Geneletti, D.; Brogaard, S.; Aukes, E.; Ciolli, M.; Grossmann, C.; Hernández-Morcillo, M.; et al. Mapping Europe's institutional landscape for forest ecosystem service provision, innovations and governance. Ecosyst. Serv. 2021, 47, 101225. [CrossRef]

17. Orsi, F.; Ciolli, M.; Primmer, E.; Varumo, L.; Geneletti, D. Mapping hotspots and bundles of forest ecosystem services across the European Union. Land Use Policy 2020, 99, 104840. [CrossRef]

18. Quiroga, S.; Suarez, C.; Ficko, A.; Feliciano, D.; Bouriaud, L.; Brahic, E.; Deuffic, P.; Dobsinska, Z.; Jarsky, V.; Lawrence, A.; et al. What influences European private forest owners' affinity for subsidies? For. Policy Econ. 2019, 99, 136-144. [CrossRef]

19. Nichiforel, L.; Keary, K.; Deuffic, P.; Weiss, G.; Thorsen, B.J.; Winkel, G.; Avdibegović, M.; Dobšinská, Z.; Feliciano, D.; Gatto, P.; et al. How private are Europe's private forests? A comparative property rights analysis. Land Use Policy 2018, 76, 535-552. [CrossRef]

20. Salzman, J. Creating Markets for Ecosystem Services: Notes from the Field-NYU Law Review. Available online: https://www. nyulawreview.org/issues/volume-80-number-3/creating-markets-for-ecosystem-services-notes-from-the-field/ (accessed on 27 May 2021).

21. Kemkes, R.J.; Farley, J.; Koliba, C.J. Determining when payments are an effective policy approach to ecosystem service provision. Ecol. Econ. 2010, 69, 2069-2074. [CrossRef]

22. Mikša, K.; Kalinauskas, M.; Inácio, M.; Gomes, E.; Pereira, P. Ecosystem services and legal protection of private property: Problem or solution? Geogr. Sustain. 2020, 1, 173-180. [CrossRef]

23. Mäntymaa, E.; Juutinen, A.; Tyrväinen, L.; Karhu, J.; Kurttila, M. Participation and compensation claims in voluntary forest landscape conservation: The case of the Ruka-Kuusamo tourism area, Finland. J. For. Econ. 2018, 33, 14-24. [CrossRef]

24. Ryan, R.M.; Deci, E.L. Intrinsic and Extrinsic Motivations: Classic Definitions and New Directions. Contemp. Educ. Psychol. 2000, 25, 54-67. [CrossRef] [PubMed]

25. Lindhjem, H.; Mitani, Y. Forest owners' willingness to accept compensation for voluntary conservation: A contingent valuation approach. J. For. Econ. 2012, 18, 290-302. [CrossRef]

26. Juutinen, A.; Tolvanen, A.; Koskela, T. Forest owners' future intentions for forest management. For. Policy Econ. 2020, 118, 102220. [CrossRef]

27. Lodin, I.; Brukas, V. Ideal vs real forest management: Challenges in promoting production-oriented silvicultural ideals among small-scale forest owners in southern Sweden. Land Use Policy 2021, 100, 104931. [CrossRef]

28. Nordlund, A.; Westin, K. Forest Values and Forest Management Attitudes among Private Forest Owners in Sweden. Forests 2010, 2, 30-50. [CrossRef]

29. Kaliszewski, A.; Młynarski, W.; GoŁos, P. Czynniki ograniczajce zalesianie gruntów porolnych w Polsce w świetle badań ankietowych. (Factors limiting afforestation of post-agricultural lands in Poland according to the survey results). Sylwan 2016, $160,846-854$. 
30. Wysocka-Fijorek, E.; Gil, W.; Gołos, P.; Dobrowolska, E. Who applies for afforestation subsidies? Analysis of the age of beneficiaries of the Rural Development Program from 2004-2018. Folia For. Pol. 2020, 62, 279-287. [CrossRef]

31. Wysocka-Fijorek, E. Indukcyjna metodyka prognozy rozwoju zasobów drzewnych. (Inductive methodology of the forecast of wood resources development). Sylwan 2020, 164, 267-279.

32. Główny Urząd Statystyczny/Obszary Tematyczne/Rolnictwo. Leśnictwo/Rolnictwo/Środki Produkcji w Rolnictwie w 2005 r. Available online: https://stat.gov.pl/obszary-tematyczne/rolnictwo-lesnictwo/rolnictwo/uzytkowanie-gruntow-ipowierzchnia-zasiewow-w-2019-roku,8,15.html\# (accessed on 27 May 2021).

33. WISL-Wielkoobszarowa Inwentaryzacja Stanu Lasu. Available online: http://wisl.pl/ (accessed on 27 May 2021).

34. Gołos, P. Stan Lasów Prywatnych w Polsce. Leśne Prace Badawcze 2008, 69, 321-335.

35. Gołos, P. Private forests in Poland-The results of the questionnaire surveys covering the network of test forest holdings. Folia For. Pol. Ser. A 2011, 53, 25-42. [CrossRef]

36. Główny Urząd Statystyczny/Obszary Tematyczne/Roczniki Statystyczne/Roczniki Statystyczne/Rocznik Statystyczny Handlu Zagranicznego. 2020. Available online: https://stat.gov.pl/obszary-tematyczne/roczniki-statystyczne/roczniki-statystyczne/ rocznik-statystyczny-lesnictwa-2020,13,3.html (accessed on 27 May 2021).

37. Cameron, R.; Richard, M.; Carson, T. Using Surveys to Value Public Goods the Contingent Valuation Method. Land Econ. 1990, 66, 107. [CrossRef]

38. Venkatachalam, L. The contingent valuation method: A review. Environ. Impact Assess. Rev. 2004, 24, 89-124. [CrossRef]

39. Bateman, I.J.; Langford, I.H.; Munro, A.; Starmer, C.; Sugden, R. Estimating four Hicksian welfare measures for a public good: A contingent valuation investigation. Land Econ. 2000, 76, 355-373. [CrossRef]

40. Cohen, R.A. Introducing the Glmselect Procedure for Model Selection. In Proceedings of the Thirty-First Annual SAS Users Group, San Francisco, CA, USA, 26-29 March 2006; pp. 1-18.

41. SAS/STAT ${ }^{\circledR} 14.3$ User's Guide High-Performance Procedures. 2017. Available online: https://support.sas.com/documentation/ onlinedoc/stat/hp_examples/143/index.html (accessed on 27 May 2021).

42. Archiwum Kursów Walut. Available online: https:/ / rss.nbp.pl/kursy/TabRss.aspx?n=2019/a/19a084 (accessed on 27 May 2021).

43. Sarvašová, Z.; Quiroga, S.; Suárez, C.; Ali, T.; Lukmine, D.; Đorđević, I.; Hrib, M. Understanding the drivers for Natura 2000 payments in forests: A Heckman selection analysis. J. Nat. Conserv. 2018, 46, 28-37. [CrossRef]

44. Sarvašová, Z.; Ali, T.; Đorđević, I.; Lukmine, D.; Quiroga, S.; Suárez, C.; Hrib, M.; Rondeux, J.; Mantzanas, K.T.; Franz, K. Natura 2000 payments for private forest owners in Rural Development Programmes 2007-2013-A comparative view. For. Policy Econ. 2019, 99, 123-135. [CrossRef]

45. Główny Urząd Statystyczny/Opracowania Sygnalne/Komunikaty i Obwieszczenia/Lista Komunikatów i Obwieszczeń/Obwie szczenie w Sprawie Wskaźnika Cen Dóbr Inwestycyjnych za Pierwszy Kwartał 2021 r. Available online: https://stat.gov.pl/ sygnalne/komunikaty-i-obwieszczenia/lista-komunikatow-i-obwieszczen/komunikat-w-sprawie-sredniej-ceny-sprzedazydrewna-obliczonej-wedlug-sredniej-ceny-drewna-uzyskanej-przez-nadlesnictwa-za-pierwsze-trzy-kwartaly-2019-roku,268,6 html (accessed on 27 May 2021).

46. Polomé, P. Private forest owners motivations for adopting biodiversity-related protection programs. J. Environ. Manag. 2016, 183, 212-219. [CrossRef] [PubMed]

47. Mutandwa, E.; Grala, R.K.; Petrolia, D.R. Estimates of willingness to accept compensation to manage pine stands for ecosystem services. For. Policy Econ. 2019, 102, 75-85. [CrossRef]

48. Erickson, D.L.; Lovell, S.T.; Méndez, V.E. Landowner willingness to embed production agriculture and other land use options in residential areas of Chittenden County, VT. Landsc. Urban Plan. 2011, 103, 174-184. [CrossRef]

49. Hily, E.; Garcia, S.; Stenger, A.; Tu, G. Assessing the cost-effectiveness of a biodiversity conservation policy: A bio-econometric analysis of Natura 2000 contracts in forest. Ecol. Econ. 2015, 119, 197-208. [CrossRef]

50. Vedel, S.E.; Jacobsen, J.B.; Thorsen, B.J. Forest owners' willingness to accept contracts for ecosystem service provision is sensitive to additionality. Ecol. Econ. 2015, 113, 15-24. [CrossRef]

51. Mäntymaa, E.; Juutinen, A.; Mönkkönen, M.; Svento, R. Participation and compensation claims in voluntary forest conservation: A case of privately owned forests in Finland. For. Policy Econ. 2009, 11, 498-507. [CrossRef]

52. Kilgore, M.A.; Snyder, S.A.; Schertz, J.; Taff, S.J. What does it take to get family forest owners to enroll in a forest stewardship-type program? For. Policy Econ. 2008, 10, 507-514. [CrossRef]

53. Timmons, D. Using former farmland for biomass crops: Massachusetts landowner motivations and willingness to plant. Agric. Resour. Econ. Rev. 2014, 43, 419-437. [CrossRef]

54. LeVert, M.; Stevens, T.; Kittredge, D. Willingness-to-sell conservation easements: A case study. J. For. Econ. 2009, 15, 261-275. [CrossRef]

55. Tyrväinen, L.; Mäntymaa, E.; Juutinen, A.; Kurttila, M.; Ovaskainen, V. Private landowners' preferences for trading forest landscape and recreational values: A choice experiment application in Kuusamo, Finland. Land Use Policy 2020, $107,104478$. [CrossRef]

56. Bartczak, A.; Metelska-Szaniawska, K. Should we pay, and to whom, for biodiversity enhancement in private forests? An empirical study of attitudes towards payments for forest ecosystem services in Poland. Land Use Policy 2015, 48, 261-269. [CrossRef] 